\title{
Determination of digestible and available amino acids in meat meal using conventional and caecectomized cockerels or chick growth assays
}

\author{
BY CARL M. PARSONS* \\ Department of Animal Sciences, University of Illinois, Urbana, Illinois 61801, USA
}

(Received 11 April 1985-Accepted 5 February 1986)

\begin{abstract}
1. The present study was designed to compare true digestible amino acid values for meat meal with available amino acid values. True digestible values were determined with a $48 \mathrm{~h}$ excreta collection assay using conventional (CONV) and caecectomized (CEC) cockerels. Available values for lysine, methionine and cystine were estimated by chick growth assays.

2. True digestibilities of all sixteen measured amino acids (expressed as a proportion of the total) were lower for CEC than for CONV cockerels, with the average difference being approximately $0 \cdot 10$.

3. Chick growth assays based on total weight gain indicated that the availabilities of amino acids expressed as a proportion of the total amino acids in meat meal were: 0.70 for lysine, 0.75 for methionine and 0.48 for cystine. Partitioning weight gains to reflect only growth attributable to supplemental crystalline amino acid or meat meal intake consistently yielded higher avajlability values than when total weight gains were used.

4. True digestibility values determined with CEC cockerels were in better agreement with chick available values than were true digestibility values determined with CONV cockerels.

5. The amounts of amino acids present in the caeca of meat meal-fed CONV cockerels at $48 \mathrm{~h}$ after feeding were small when compared with those levels voided in the excreta and those levels consumed in the feed.

6. Multiple regression analyses of excreta and caecal amino acid profiles at 12 and $48 \mathrm{~h}$ after feeding suggested that significant amounts of non-digested dietary amino acids flowed into the caeca and were subsequently metabolized by the caecal microflora.
\end{abstract}

Meat meals are widely used in animal feeding programmes. The protein quality of the meals can vary greatly depending upon the composition of the raw materials and the processing conditions used (Johnston \& Coon, 1979a). There is a need for rapid, inexpensive and accurate methods for assessing protein quality of meat meals so that manufacturers and nutritionists can monitor and consistently produce meals of high nutritional value. The quality of meat meals is usually estimated by the pepsin digestibility method of the Association of Official Analytical Chemists (AOAC, 1975). This is an in vitro assay and does not always correlate well with in vivo protein utilization (Johnston \& Coon, 1979b). A rapid and inexpensive assay to determine in vivo amino acid (AA) availability would be more useful.

The chick growth assay is a standard method used to assess biological availability of AA (Combs et al., 1968). This assay determines availability based on animal performance, which includes all of the processes of digestion, absorption and utilization of the AA. However, this procedure is time-consuming and expensive, and the availability of only one AA can be assessed per assay. A much more rapid procedure that appears to have great potential for routine determination of in vivo AA availability is the excreta collection assay described by Sibbald (1979). This assay requires only $48 \mathrm{~h}$, and all AA can be evaluated simultanecusly. This assay basically measures 'digestibility' of AA since the values are calculated from the difference between quantity of AA consumed and that voided in the excreta. The assay does not measure 'digestibility' as classically defined since both the faeces and urine are collected; however, Terpstra (1977) has shown that the urinary AA contribution to total excreta AA is small and usually has a negligible effect on calculated digestibility values.

* Present address: 322 Mumford Hall, 1301 W. Gregory Drive, Urbana, Illinois 61801, USA. 
Digestibility assays differ from availability assays (growth) because only digestion and absorption of AA are measured in the former. As shown by Achinewhu \& Hewitt (1979), digestibility values provide a good measure of the availability of AA in some materials but not others.

The accuracy of the excreta collection method is questionable because of intestinal absorption of non-nutritive AA derivatives (Zebrowska, 1973; Robbins \& Baker, 1980) and unknown effects of hind-gut micro-organisms on AA excretion (Salter, 1973). It is well known that the latter effects are large with species such as swine and rats, but their significance with poultry is unclear (Parsons, 1985). Several studies with germ-free chicks have yielded variable results concerning the effects of hind-gut bacteria on AA excretion by poultry (Salter \& Coates, 1971; Salter et al. 1974; Salter \& Fulford, 1974; Elwell \& Soares, 1975).

Recent research indicates that the caecectomized (CEC) bird may be a better model for estimating AA availability than the conventional (CONV) bird. Removal of the caeca should markedly reduce microbial activity in the hind-gut, since the caeca account for the majority of the capacity in the region posterior to the small intestine. Parsons (1984) concluded that intestinal microflora had less influence on AA excretion by CEC hens than on that by CONV hens. Caecectomy has several advantages compared with ileal-cannulation techniques which are used to measure AA digestibility with swine. Caecectomy is a much simpler surgical procedure than is the implantation of ileal cannulae. Caecectomized birds can be maintained much more easily than ileal-cannulated birds or pigs; there are no problems with digesta passage or flow rate, and there is no need for digesta markers since excreta can be collected quantitatively.

The present study was designed to compare true digestible AA values for meat meal determined with $\mathrm{CEC}$ cockerels with those determined with CONV cockerels. The true digestible AA values were also compared with available AA values determined by chick growth assay. The results showed that true digestibility values determined with CEC cockerels were lower than those determined with CONV cockerels and were in better agreement with chick availability values.

\section{EXPERIMENT AL}

Animals

Single Comb, White Leghorn cockerels, approximately 40 weeks of age, were used in the true digestibility and caecal AA assays. The cockerels were housed in an environmentally controlled room and kept in individual cages with raised wire floors. Artificial light was provided for $16 \mathrm{~h}$ daily and food and water were supplied ad lib. before the start of the experiments. Caecectomy was performed by the procedure of Parsons (1985). The CONV cockerels received a sham operation within a similar time period. All cockerels were given at least 8 weeks to recover from surgery before being used in experiments. Surgical examination of a sample of CEC cockerels following the assay indicated that little or no caecal regrowth had occurred.

Male chicks (New Hampshire males $\times$ Columbian) were used in the chick growth assays (Parsons et al. 1984). At hatching, the chicks were given a maize and soya-bean meal pretest diet until $7 \mathrm{~d}$ of age. They were then weighed and allocated to treatment as described by Sasse \& Baker (1974). All chicks were housed in starter batteries with raised wire floors and allowed to consume feed and water ad lib. Artificial light was provided $24 \mathrm{~h}$ daily.

\section{True digestibility assay}

The assay used was that described by Sibbald (1979) with some minor modifications. Sixteen CEC and eighteen CONV cockerels were fasted for $24 \mathrm{~h}$, weighed, and allocated to 
treatment so that average body-weights of birds on each treatment were similar. Nine CEC and eleven CONV cockerels were then given $30 \mathrm{~g}$ of a commercial meat meal by crop intubation. Crop intubation was performed by the method of Sibbald (1983). Another seven cockerels of each type were fasted throughout the assay to measure endogenous excretion of dry matter (DM), energy and nitrogen in addition to AA as described by Sibbald (1979). A plastic tray was placed under each cage and excreta were collected quantitatively for $48 \mathrm{~h}$. The excreta samples were then lyophilized and weighed, and ground to pass through a 60-mesh screen. Chemical analyses were performed on each individual sample.

\section{Chick growth assays}

Biological availabilities of lysine and methionine plus cystine in the meat meal were determined using a purified crystalline AA basal diet (Baker et al. 1979) which contained a suboptimal level of the test AA. The availability of methionine specifically was determined using a feather-meal, soya-bean-meal basal diet. This diet was similar to the semi-purified feather-meal diet described by Boebel \& Baker (1982) except for the following ingredients and levels $(\mathrm{g} / \mathrm{kg})$ : feather meal $151 \cdot 0$, dehulled soya-bean meal $151 \cdot 0$, L-lysine hydrochloride $7 \cdot 98$, L-tryptophan $0 \cdot 44$, L-histidine hydrochloride monohydrate $3 \cdot 2$. This diet contains $1 \cdot 7 \mathrm{~g}$ methionine $/ \mathrm{kg}$ and $7.4 \mathrm{~g}$ cystine $/ \mathrm{kg}$ from calculation. Thus, the diet was deficient in methionine but contained a plethora of cystine. It was formulated to contain a cystine concentration well in excess of the requirement because Baker et al. (1981) reported that the availability of cystine in feather-meal is low. A standard curve was derived for each assay by adding two or three levels of the test AA to the basal diet deficient in the test AA. Likewise, increasing levels of meat meal were added to the basal diet, replacing maize starch, to provide amounts of AA potency that would fall within the boundaries of the standard curve. At least two, and usually three, levels of meat meal were included so that thorough statistical validity tests could be conducted. All treatments (test AA standards and meat meal) were conducted concurrently within assays. Two separate availability assays were conducted for methionine plus cystine. The basal and supplemental levels of methionine and cystine were varied between these assays because Katz \& Baker (1975) have shown that the methionine-sparing value of cystine varies with dietary sulphur AA adequacy. The methionine-sparing value of cystine could influence the growth response obtained from sulphur AA supplementation and, in turn, affect calculated availability values. Experimental diets in all assays were given to triplicate groups of five chicks from 8 to $16 \mathrm{~d}$ after hatching.

\section{Caecal amino acid assay}

An additional assay was conducted to measure the amounts of AA present in the caeca of meat-meal-fed CONV cockerels at $48 \mathrm{~h}$ after feeding. It was hypothesized that the higher AA digestibility values observed for CONV as compared with CEC birds might be due to retention of undigested dietary AA in the caeca, resulting in less AA being voided in the excreta. The basic procedures were the same as described previously for the true digestibility assay. Twenty CONV cockerels were fasted for $24 \mathrm{~h}$ and then ten cockerels were given $35 \mathrm{~g}$ meat meal by crop intubation. Another ten cockerels were fasted throughout the assay. Excreta were then collected quantitatively for either 12 or $48 \mathrm{~h}$. At these times, five fasted cockerels and five cockerels given meat meal were killed by intracardial injection with sodium phenobarbitol. The caeca were removed and their contents collected quantitatively by flushing with distilled water and very gently scraping with a spatula. The individual excreta and caecal samples were processed as described previously except that AA analyses were performed on a single pooled sample for each treatment. 


\section{Chemical analyses}

Moisture, crude protein $(\mathrm{N} \times 6 \cdot 25)$, diethyl ether extract, ash, calcium, phosphorus, sodium, and pepsin digestibilities for duplicate samples of the meat meal were determined by standard procedures (AOAC, 1975). Methods used for gross energy, $\mathrm{N}$ and AA analyses on duplicate samples of the meat meal, excreta and caecal contents were the same as those described by Parsons et al. (1982, 1983). Values for aspartate, threonine, serine, glutamate, proline, glycine, alanine, cystine, valine, methionine, isoleucine, leucine, tyrosine, pheny]alanine, histidine, lysine and arginine were determined. Glycine was omitted in all statistical calculations due to breakdown of uric acid to glycine during acid hydrolysis of excreta (Soares et al. 1971). The variation between duplicate AA analyses on the same sample averaged approximately $5 \%$ of the mean.

\section{Statistical calculations and analyses}

True digestibility of AA was calculated by the method of Sibbald (1979), true metabolizable energy (TME) by the method of Sibbald (1976), and TME corrected to N equilibrium $\left(\mathrm{TME}_{\mathrm{N}}\right)$ and dry matter digestibility by the method of Parsons et al. (1982). The fasted, CEC cockerels were used to make the endogenous corrections for CEC cockerels given meat meal and, likewise, fasted, CONV cockerels were used to correct CONV cockerels given meat meal. True digestibility values for AA are expressed as a proportion of the total AA in meat meal.

Results were assessed by analysis of variance (Steel \& Torrie, 1960). Student's $t$ test was used to detect treatment differences in the digestibility assay. Availability of AA in the chick growth assays was estimated using slope-ratio methodology (Finney, 1978). Multiple regressions were computed with total chick weight gain $(Y)$ as the dependent variable and level of supplemental test AA $\left(X_{1}\right)$ and meat meal AA $\left(X_{2}\right)$ consumed as the independent variables. The calculated ratio of the slope of the meat meal response line to the test AA response line yields the amount of available AA expressed as a proportion of the total. The growth data were evaluated as a function of the test or ingredient AA consumed rather than as a function of test or ingredient AA concentration because de Meulenaere et al. (1967) reported that the former method is subject to less variation, is less influenced by the effects of other dietary factors in the test ingredient, and should give a better approximation of true availability.

In addition, available AA values were computed from multiple regression analyses where weight gain of chicks given the test diets was partitioned to reflect only gain attributable to supplemental AA or meat meal AA consumed (Netke \& Scott, 1970). Method C of Netke \& Scott (1970) was used in the lysine and methionine plus cystine assays. Weight gains of chicks given the basal diet and diets containing only supplemental crystalline test AA were regressed on the total intake of test AA (basal plus supplemental). The resulting regression equation represented weight gain as a function of crystalline test AA intake, usually referred to as the AA efficiency ratio (Baker, 1978). The crystalline AA intake of basal origin for chicks given diets containing supplemental meat meal was then calculated and substituted into this regression equation to yield the weight gain that was due to the basal AA intake. These weight gain values were subtracted from the total (observed) gain values for chicks given meat meal diets to yield the weight gain that was due solely to the supplemental meat meal. This same procedure was also used for the test AA standard curve to yield the weight gains due only to the supplemental test AA. Theoretically, the weight gain due to supplemental AA for chicks given the basal diet should be zero. However, this value differed from zero slightly, but not significantly $(P>0 \cdot 10)$, because the mean AA efficiency ratio for the triplicate groups of chicks given the basal diet was not identical to 
the AA efficiency ratio computed from the regression (above) of weight gain on total crystalline test AA intake of chicks given the basal and basal plus supplemental test AA diets. Since the basal diet in the methionine assay contained methionine from intact protein (unknown availability), the mean gain per $\mathrm{mg}$ of calculated methionine consumed for chicks given the unsupplemented basal (treatment 1) was used to partition the weight gains of chicks given the other test diets.

Availability of AA based on partitioned growth values was calculated by the slope-ratio procedures described previously with the partitioned weight gain values as the dependent variable $(Y)$. Validity tests for blanks, curvature, and intersection effects were performed on all regression analyses (partitioned and nonpartitioned) as described by Finney (1978). The blanks component represents the deviation between the computed intercept from the regression on all data and the computed intercept obtained from the regression on non-zero doses only; thus, it provides a test of whether the equation remains valid down to zero dose (basal). The intersection component tests the difference in expected responses to zero dose calculated from lines fitted to the test AA and test ingredient separately (simple linear regressions). The curvature component tests the degree of curvature in the individual response lines, excluding zero dose.

The influence of dietary, endogenous and microbial protein on excreta and caecal AA profiles was evaluated in the digestibility and caecal retention assays with multiple regression methodology where the model was:

$$
Y=b_{0}+b_{1} X_{1}+b_{2} X_{2}+b_{3} X_{3}
$$

where $Y$ is the AA composition (mmol/mol of total AA) of the excreta or caecal contents, $X_{1}$ is the AA composition of dietary meat meal, $X_{2}$ is the AA composition of endogenous digesta collected from the terminal ileum of surgically modified cockerels given a $\mathrm{N}$-free diet (Parsons et al. 1983), and $X_{3}$ is the AA composition of microbial cells harvested from poultry excreta (Parsons et al. 1981). This regression procedure has been described by Mendes-Periera et al. (1977) and Parsons (1984). Histidine was not included in these regressions due to variation in AA analysis methods among studies. Regression coefficients were compared statistically by methods outlined by Steel \& Torrie (1960).

\section{RESULTS}

\section{Composition of meat meal}

In general, the composition of the meat meal was intermediate to those listed by the (US) National Research Council (NRC, 1977) for meat meal (5-00-385) and meat and bone meal (5-00-388) (Table 1). However, the cystine level was much higher than that listed by the NRC (1977), suggesting that the meat meal used in the present study contained a high level of connective tissue and keratin protein. The high cystine concentration may have also partially originated from lanthionine sulphone. Performic acid oxidation (for analysis of methionine and cystine) converts lanthionine to lanthionine sulphone which has a similar retention time to cysteic acid during ion-exchange chromatography (Baker et al. 1981). Pepsin digestibility of the meat meal was $682.5 \mathrm{~g} / \mathrm{kg}$.

\section{True digestibility assay}

True digestibilities of DM, TME and TME ${ }_{\mathrm{N}}$ were higher for CONV than for CEC cockerels (Table 2). $\mathrm{N}$ retention was similar between bird types. As expected, $\mathrm{TME}_{\mathrm{N}}$ was lower than TME. True digestibilities of all measured AA were lower for CEC than for CONV cockerels, with differences being greatest for aspartate, cystine, serine and proline. Digestibilities for CEC cockerels of aspartate and cystine were the lowest of the measured AA. Mean digestibility for all AA was about $0 \cdot 10$ lower for CEC than for CONV cockerels. 
Table 1. Composition of meat meal $(\mathrm{g} / \mathrm{kg})$

(Values are expressed on an air-dry basis)

\begin{tabular}{lr}
\hline Moisture & $60 \cdot 9$ \\
Crude protein (nitrogen $\times 6 \cdot 25)$ & $510 \cdot 0$ \\
Diethyl ether extract & $119 \cdot 0$ \\
Ash & $344 \cdot 0$ \\
Calcium & $68 \cdot 0$ \\
Phosphorus & $32 \cdot 4$ \\
Sodium & $5 \cdot 8$ \\
Pepsin digestibility* & $682 \cdot 5$ \\
Amino acids: & \\
Aspartic acid & $43 \cdot 6$ \\
Threonine & $23 \cdot 0$ \\
Serine & $24 \cdot 8$ \\
Glutamic acid & $66 \cdot 0$ \\
Proline & $43 \cdot 8$ \\
Glycine & $72 \cdot 3$ \\
Alanine & $37 \cdot 1$ \\
Cystine & $6 \cdot 0$ \\
Valine & $24 \cdot 3$ \\
Methionine & $6 \cdot 2$ \\
Isoleucine & $14 \cdot 2$ \\
Leucine & $33 \cdot 5$ \\
Tyrosine & $11 \cdot 8$ \\
Phenylalanine & $18 \cdot 0$ \\
Histidine & $10 \cdot 8$ \\
Lysine & $24 \cdot 4$ \\
Arginine & $34 \cdot 7$ \\
Total & $494 \cdot 5$ \\
\hline A & \\
\hline \hline
\end{tabular}

* Pepsin-digestible N (Association of Official Analytical Chemists, 1975) corrected for acid blank by the method of Johnston \& Coon $(1979 a)$.

Chick growth assays

Linear improvements in rate of gain and weight gain : food intake $(P<0.01)$ were obtained from AA and meat-meal supplementation of the basal diets in all assays (Tables 3 and 4). Validity tests (Finney, 1978) for regression analyses using total weight gains indicated no significant blanks, intersection or curvature effects except for bioassay no. 2 (Table 4). A significant blanks effect was detected for this assay; thus, treatment 1 was omitted from the analyses. From multiple regression analyses of total chick weight gains, the ratio of slopes indicated that the availabilities of lysine and methionine were 0.70 and 0.75 respectively (Table 3 ). The results of the two assays for methionine plus cystine were similar (Table 4). They indicated that availability of methionine plus cystine was approximately $0 \cdot 62$. From the results of the methionine plus cystine and the specific methionine assays, the availability of cystine was calculated by difference. These calculations indicated a mean availability of 0.48 for cystine.

Availability values computed from weight gains that were partitioned to reflect only gain due to supplemental test or meat meal AA intake were consistently higher than those computed from total weight gains (Tables 3 and 4). Validity tests for these regressions indicated no significant deviation effects except for an intersection effect in the lysine bioassay. This effect was due primarily to the performance of chicks given supplemental meat meal, with the response to the first supplemental level of meat meal being somewhat greater in proportion than the response to the second. However, the lysine availability estimate 
Table 2. Influence of caecectomy on utilization of meat meal by cockerels

(Values are means for eleven and nine cockerels each for conventional and caecectomized treatments respectively)

\begin{tabular}{|c|c|c|c|c|}
\hline & \multicolumn{2}{|c|}{ Bird type } & \multirow[b]{2}{*}{ SED } & \multirow{2}{*}{$\begin{array}{l}\text { Statistical } \\
\text { significance of } \\
\text { difference }\end{array}$} \\
\hline & Conventional & Caecectomized & & \\
\hline $\begin{array}{l}\text { True digestibility of DM } \\
\text { (g/g of total) }\end{array}$ & $0 \cdot 56$ & 0.51 & $0 \cdot 022$ & * \\
\hline $\mathrm{N}$ retained $(\mathrm{g})$, apparent & -0.05 & 0.06 & $0 \cdot 188$ & NS \\
\hline TME $(\mathrm{kJ} / \mathrm{g}) \dagger$ & $14 \cdot 17$ & $12 \cdot 87$ & 0.285 & $* *$ \\
\hline $\operatorname{TME}_{\mathrm{N}}(\mathrm{kJ} / \mathrm{g}) \dagger$ & $12 \cdot 53$ & $11 \cdot 34$ & 0.259 & $* *$ \\
\hline \multicolumn{5}{|l|}{$\begin{array}{l}\text { True digestibility of amino } \\
\text { acids }(\mathrm{g} / \mathrm{g} \text { of total): }\end{array}$} \\
\hline Aspartic acid & 0.85 & $0 \cdot 62$ & 0.022 & $* *$ \\
\hline Threonine & 0.91 & 0.81 & 0.016 & ** \\
\hline Serine & 0.90 & 0.76 & 0.018 & $* *$ \\
\hline Glutamic acid & 0.89 & 0.79 & 0.015 & $* *$ \\
\hline Proline & 0.88 & 0.75 & 0.018 & $* *$ \\
\hline Alanine & 0.88 & $0 \cdot 80$ & 0.015 & $* *$ \\
\hline Cystine & $0 \cdot 73$ & 0.59 & 0.038 & $* *$ \\
\hline Valine & $0 \cdot 88$ & 0.81 & 0.017 & $* *$ \\
\hline Methionine & 0.85 & 0.75 & 0.033 & $* *$ \\
\hline Isoleucine & 0.88 & 0.84 & 0.017 & $*$ \\
\hline Leucine & 0.89 & 0.84 & 0.014 & $* *$ \\
\hline Tyrosine & $0 \cdot 88$ & 0.82 & 0.019 & $* *$ \\
\hline Phenylalanine & 0.90 & 0.84 & 0.016 & $* *$ \\
\hline Histidine & $0 \cdot 84$ & 0.76 & 0.025 & $* *$ \\
\hline Lysine & 0.87 & 0.79 & 0.015 & $* *$ \\
\hline Arginine & 0.92 & $0 \cdot 84$ & 0.012 & $* *$ \\
\hline Mean & 0.87 & 0.77 & - & - \\
\hline
\end{tabular}

NS, not significant $(P>0.05)$; DM, dry matter; TME, true metabolizable energy; $\mathrm{TME}_{\mathrm{N}}$, TME corrected to $\mathrm{N}$ equilibrium; SED, standard error of the difference.

${ }^{*} P<0.05, * * P<0.01$.

$\dagger \mathrm{DM}$ basis.

appeared to be reasonably accurate as it was slightly higher than the estimate based on total weight gain; the same pattern was observed in the other assays. The partitioned weight gain values of chicks given the basal diets (treatment 1 ) in the lysine and methionine plus cystine assays were small and not significantly different from zero $(P>0 \cdot 10)$.

\section{Caecal amino acid assay}

The amount of DM present in the caeca at the end of the $48 \mathrm{~h}$ trial was small compared with that voided in the excreta by both fasted cockerels and cockerels given meat meal (Table 5). The levels of seven AA in the caeca of cockerels given meat meal were small when compared with levels voided in the excreta and were negligible when compared with levels of AA consumed from the meat meal. The levels of AA present in the caeca of fasted birds, however, were significant when compared with those voided in excreta. Expressing the levels of AA in the caeca of fasted cockerels relative to those voided in excreta yielded values ranging from 0.16 for cystine to 0.43 for methionine. The levels of DM and AA in caeca of fasted cockerels were not markedly different from those present in caeca of cockerels given meat meal. 
Table 3. Determination of lysine and methionine availability (proportion of total) in meat meal (MM) using a slope-ratio chick bioassay

(Values are means of triplicate groups of five male chicks from 8 to $16 \mathrm{~d}$ after hatching)

\begin{tabular}{|c|c|c|c|c|c|c|}
\hline \multirow[b]{2}{*}{ Treatments } & \multicolumn{2}{|c|}{ Wt gain $(g)$} & \multirow{2}{*}{$\begin{array}{l}\text { Food } \\
\text { intake } \\
\quad(\mathrm{g})\end{array}$} & \multirow{2}{*}{$\begin{array}{c}\text { Total } \\
\text { wt gain : food intake } \\
(\mathrm{g} / \mathrm{g})\end{array}$} & \multicolumn{2}{|c|}{$\begin{array}{l}\text { Amino acid } \\
\text { availability } \\
\text { (g/g of total })^{\dagger}\end{array}$} \\
\hline & Total & Partitioned* & & & Mean & $\mathrm{SE}$ \\
\hline \multicolumn{7}{|c|}{ Lysine bioassay } \\
\hline $\begin{array}{l}\text { 1. Basal }(4 \cdot 0 \mathrm{~g} \\
\text { L-lysine } / \mathrm{kg})\end{array}$ & $30 \cdot 0$ & $-1 \cdot 4$ & $76 \cdot 7$ & $0 \cdot 392$ & $0 \cdot 702$ & 0.065 \\
\hline $\begin{array}{r}\text { 2. Basal }+1.0 \mathrm{~g} \\
\text { L-lysine } / \mathrm{kg}\end{array}$ & $46 \cdot 5$ & $8 \cdot 5$ & $94 \cdot 4$ & 0.492 & $(0 \cdot 750)$ & $(0 \cdot 103)$ \\
\hline $\begin{array}{r}\text { 3. Basal }+2 \cdot 0 \mathrm{~g} \\
\text { L-lysine } / \mathrm{kg}\end{array}$ & $68 \cdot 6$ & $24 \cdot 0$ & $112 \cdot 5$ & 0.611 & - & - \\
\hline $\begin{array}{r}\text { 4. Basal }+3 \cdot 0 \mathrm{~g} \\
\text { L-lysine } / \mathrm{kg}\end{array}$ & $92 \cdot 1$ & $37 \cdot 2$ & $140 \cdot 1$ & 0.657 & - & - \\
\hline $\begin{array}{c}\text { 5. Basal }+50 \mathrm{~g} \\
\mathrm{MM} / \mathrm{kg}\end{array}$ & $46 \cdot 9$ & $12 \cdot 8$ & $84 \cdot 0$ & 0.559 & - & - \\
\hline $\begin{array}{l}\text { 6. Basal + } 100 \mathrm{~g} \\
\mathrm{MM} / \mathrm{kg}\end{array}$ & $56 \cdot 5$ & $16 \cdot 1$ & 100.8 & 0.561 & - & - \\
\hline Pooled SE & $3 \cdot 2$ & $1 \cdot 5$ & $5 \cdot 9$ & 0.016 & - & - \\
\hline \multicolumn{7}{|c|}{ Methionine bioassay $\ddagger$} \\
\hline $\begin{array}{l}\text { 1. Basal }(1 \cdot 7 \mathrm{~g} \\
\mathrm{L} \text {-methionine } / \mathrm{kg})\end{array}$ & $32 \cdot 6$ & $0 \cdot 0$ & 71.9 & 0.451 & 0.752 & 0.076 \\
\hline $\begin{array}{l}\text { 2. Basal }+0.5 \mathrm{~g} \\
\text { L-methionine } / \mathrm{kg}\end{array}$ & $57 \cdot 8$ & $12 \cdot 4$ & $100 \cdot 1$ & 0.577 & $(0 \cdot 812)$ & $(0.052)$ \\
\hline $\begin{array}{l}\text { 3. Basal }+1.0 \mathrm{~g} \\
\mathrm{~L} \text {-methionine } / \mathrm{kg}\end{array}$ & 81.9 & $25 \cdot 8$ & $123 \cdot 2$ & 0.664 & - & - \\
\hline $\begin{array}{c}\text { 4. Basal }+50 \mathrm{~g} \\
\mathrm{MM} / \mathrm{kg}\end{array}$ & $37 \cdot 3$ & $4 \cdot 0$ & $73 \cdot 6$ & $0 \cdot 504$ & - & - \\
\hline $\begin{array}{l}\text { 5. Basal }+100 \mathrm{~g} \\
\mathrm{MM} / \mathrm{kg}\end{array}$ & $52 \cdot 6$ & $10 \cdot 8$ & $92 \cdot 1$ & $0 \cdot 571$ & - & - \\
\hline $\begin{array}{l}\text { 6. Basal }+150 \mathrm{~g} \\
\mathrm{MM} / \mathrm{kg}\end{array}$ & $60 \cdot 6$ & $15 \cdot 8$ & $98 \cdot 7$ & 0.614 & - & - \\
\hline Pooled SE & $2 \cdot 8$ & $1 \cdot 0$ & $4 \cdot 2$ & 0.010 & - & - \\
\hline
\end{tabular}

* Weight gains partitioned to reflect only gain due to supplemental crystalline amino acid or MM intake by the procedure of Netke \& Scott (1970). The reference standard curve from regression of total gain $(Y ; \mathrm{g})$ on total lysine intake $(X ; \mathrm{mg})$ was

$$
Y=3 \cdot 0+0 \cdot 0925 X \text {. }
$$

The mean gain (g) per mg methionine intake from treatment no. $1(0 \cdot 2667)$ was used to partition the weight gains in the methionine assay.

t Mean values with their standard errors for available amino acid were calculated from slope-ratio analysis for multiple regression of total gain (g) on supplemental test amino acid or MM amino acid intake $\left(r^{2} 0.97\right.$ for lysine assay: $r^{2} 0.94$ for methionine assay). Values in parentheses calculated using partitioned gains.

¥ Basal diet used in the lysine assay was a crystalline amino acid diet adequate in all amino acids except lysine; the basal diet used in the methionine assay was a feather-meal, soya-bean-meal diet containing $1.7 \mathrm{~g}$ methionine $/ \mathrm{kg}$ and $7.4 \mathrm{~g}$ cystine $/ \mathrm{kg}$.

\section{Regression analyses of amino acid profiles}

Results of the multiple regression analyses to evaluate the influence of dietary, endogenous and microbial protein compositions on AA profiles of excreta and caecal contents are presented in Table 6 (digestibility assay) and Table 7 (caecal amino acid assay). In the digestibility assay (Table 6), regression coefficients for dietary protein were significant 
Table 4. Determination of availability of methionine plus cystine (Met and Cys) in meat meal (MM) using a slope-ratio chick bioassay

(Values are means of triplicate groups of five male chicks from 8 to $16 \mathrm{~d}$ after hatching)

\begin{tabular}{|c|c|c|c|c|c|c|}
\hline \multirow[b]{2}{*}{ Treatments } & \multicolumn{2}{|c|}{ Wt gain (g) } & \multirow{2}{*}{$\begin{array}{l}\text { Food } \\
\text { intake } \\
\text { (g) }\end{array}$} & \multirow{2}{*}{$\begin{array}{c}\text { Total } \\
\text { wt gain : food intake } \\
(\mathrm{g} / \mathrm{g})\end{array}$} & \multicolumn{2}{|c|}{$\begin{array}{c}\text { Amino acid } \\
\text { availability } \\
(\mathrm{g} / \mathrm{g} \text { of total }) \dagger\end{array}$} \\
\hline & Total & Partitioned ${ }^{*}$ & & & Mean & SE \\
\hline \multicolumn{7}{|c|}{ Bioassay no. $1 \neq$} \\
\hline $\begin{array}{l}\text { 1. Basal }(3 \cdot 0 \mathrm{~g} \\
\text { Met }+ \text { Cys } / \mathrm{kg})\end{array}$ & $37 \cdot 2$ & $-1 \cdot 6$ & $84 \cdot 7$ & $0 \cdot 439$ & 0.622 & $0 \cdot 072$ \\
\hline $\begin{array}{c}\text { 2. Basal }+0.8 \mathrm{~g} \\
\text { L-Met } / \mathrm{kg}\end{array}$ & $73 \cdot 4$ & $18 \cdot 0$ & $123 \cdot 0$ & $0 \cdot 597$ & $(0.665)$ & $(0 \cdot 075)$ \\
\hline $\begin{array}{c}\text { 3. Basal }+1.6 \mathrm{~g} \\
\text { L-Met } / \mathrm{kg}\end{array}$ & $93 \cdot 2$ & $30 \cdot 4$ & $139 \cdot 9$ & 0.666 & - & - \\
\hline $\begin{array}{c}\text { 4. Basal }+50 \mathrm{~g} \\
\mathrm{MM} / \mathrm{kg}\end{array}$ & $43 \cdot 5$ & $3 \cdot 1$ & $88 \cdot 7$ & 0.491 & - & - \\
\hline $\begin{array}{l}\text { 5. Basal }+100 \mathrm{~g} \\
\mathrm{MM} / \mathrm{kg}\end{array}$ & $59 \cdot 7$ & $13 \cdot 1$ & $102 \cdot 7$ & $0 \cdot 581$ & - & - \\
\hline $\begin{array}{l}\text { 6. Basal }+150 \mathrm{~g} \\
\mathrm{MM} / \mathrm{kg}\end{array}$ & $75 \cdot 3$ & $20 \cdot 9$ & $120 \cdot 7$ & 0.625 & - & - \\
\hline Pooled SE & $2 \cdot 3$ & 1.9 & $5 \cdot 9$ & 0.016 & - & - \\
\hline \multicolumn{7}{|c|}{ Bioassay no. $2 \ddagger$} \\
\hline $\begin{array}{l}\text { 1. Basal }(2.5 \mathrm{~g} \\
\text { Met }+ \text { Cys } / \mathrm{kg})\end{array}$ & $26 \cdot 8$ & $-2 \cdot 7$ & $76 \cdot 5$ & $0 \cdot 350$ & 0.614 & 0.061 \\
\hline $\begin{array}{l}\text { 2. Basal }+0.35 \mathrm{~g} \\
\text { L-Met } / \mathrm{kg}+ \\
0.35 \mathrm{~g} \mathrm{~L}-\mathrm{Cys} / \mathrm{kg}\end{array}$ & $57 \cdot 0$ & $16 \cdot 5$ & $105 \cdot 6$ & 0.540 & $(0 \cdot 708)$ & $(0.093)$ \\
\hline $\begin{array}{l}\text { 3. Basal }+0.70 \mathrm{~g} \\
\text { L-Met } / \mathrm{kg}+ \\
0.70 \mathrm{~g} \mathrm{~L}-\mathrm{Cys} / \mathrm{kg}\end{array}$ & $73 \cdot 1$ & $24 \cdot 4$ & $127 \cdot 3$ & 0.575 & - & - \\
\hline $\begin{array}{c}\text { 4. Basal }+50 \mathrm{~g} \\
\mathrm{MM} / \mathrm{kg}\end{array}$ & $47 \cdot 6$ & $8 \cdot 9$ & $100 \cdot 6$ & 0.474 & - & - \\
\hline $\begin{array}{c}\text { 5. Basal }+100 \mathrm{~g} \\
\mathrm{MM} / \mathrm{kg}\end{array}$ & $52 \cdot 8$ & $12 \cdot 3$ & $105 \cdot 4$ & 0.501 & - & - \\
\hline $\begin{array}{l}\text { 6. Basal }+150 \mathrm{~g} \\
\mathrm{MM} / \mathrm{kg}\end{array}$ & $66 \cdot 5$ & $22 \cdot 6$ & $114 \cdot 4$ & $0 \cdot 580$ & - & - \\
\hline Pooled SE & $2 \cdot 2$ & 1.9 & $2 \cdot 8$ & -0.020 & - & - \\
\hline \multicolumn{5}{|c|}{ Available cystine (bioassay no. 1 ) $\S$} & $\begin{array}{c}0.483 \\
(0.517)\end{array}$ & - \\
\hline \multicolumn{5}{|c|}{ Available cystine (bioassay no. 2 ) $\S$} & $\begin{array}{c}0.467 \\
(0.600)\end{array}$ & - \\
\hline
\end{tabular}

* See footnote, Table 3 . The reference standard curves from regression of total gain $(Y ; \mathrm{g})$ on total Met + Cys intake $(X ; \mathrm{mg})$ were

$$
Y=1 \cdot 9+0 \cdot 1450 X(\text { bioassay } 1)
$$

and

$$
Y=0 \cdot 7+0 \cdot 1509 X \text { (bioassay } 2) \text {. }
$$

$\dagger$ See footnote, Table 3. $r^{2} 0.94$ for assay $1 ; r^{2} 0.89$ for assay 2 . Values in parentheses calculated using partitioned weight gains.

$\ddagger$ Basal diet was a crystalline amino acid diet adequate in all amino acids except methionine and cystine. The basal diet in assay 1 contained $1.5 \mathrm{~g}$ each of L-methionine and L-cystine $/ \mathrm{kg}$, and the basal diet in assay 2 contained $1.5 \mathrm{~g} \mathrm{~L}$-methionine $/ \mathrm{kg}$ and $1.0 \mathrm{~g} \mathrm{~L}$-cystine $/ \mathrm{kg}$.

$\$$ Calculated by difference using the methionine + cystine value and the methionine value in Table 3 . Values in parentheses are the mean availability values calculated using partitioned weight gains. 
Table 5. Amounts of dry matter $(\mathrm{g})$ and selected amino acids $(\mathrm{mg})$ present in the feed, excreta and caeca of fasted cockerels and cockerels given $35 \mathrm{~g}$ meat meal in the caecal amino acid assay

(Values for dry matter are means with their standard errors for five cockerels each and values for amino acids are means of duplicate analyses on one pooled sample from each treatment)

\begin{tabular}{|c|c|c|c|c|c|c|c|}
\hline \multirow[b]{2}{*}{ Bird type } & \multirow{2}{*}{$\begin{array}{l}\text { Amount consumed } \\
\text { in the feed (A) } \\
\text { Mean }\end{array}$} & \multicolumn{2}{|c|}{$\begin{array}{l}\text { Amount voided } \\
\text { in excreta (B)* }\end{array}$} & \multicolumn{2}{|c|}{$\begin{array}{l}\text { Amount present } \\
\text { in caeca }(C)^{*}\end{array}$} & \multirow[b]{2}{*}{$\mathrm{C} / \mathrm{A}$} & \multirow[b]{2}{*}{$\mathrm{C} / \mathrm{B}$} \\
\hline & & Mean & $\mathrm{SE}$ & Mean & SE & & \\
\hline \multicolumn{8}{|l|}{ Fasted: } \\
\hline Dry matter & - & $7 \cdot 4$ & 0.64 & 0.38 & 0.08 & - & 0.05 \\
\hline Lysine & - & $31 \cdot 9$ & - & $11 \cdot 0$ & - & - & 0.34 \\
\hline Methionine & - & $13 \cdot 8$ & - & $6 \cdot 0$ & - & - & 0.43 \\
\hline Cystine & - & $19 \cdot 5$ & - & $3 \cdot 1$ & - & - & $0 \cdot 16$ \\
\hline Arginine & - & $29 \cdot 9$ & - & 8.9 & - & - & 0.30 \\
\hline Threonine & - & $30 \cdot 4$ & - & $9 \cdot 0$ & $\ldots$ & - & $0 \cdot 30$ \\
\hline Isoleucine & - & $20 \cdot 1$ & - & $7 \cdot 5$ & $\ldots$ & - & $0 \cdot 37$ \\
\hline Valine & - & $26 \cdot 2$ & $\cdots$ & $9 \cdot 5$ & - & - & $0 \cdot 36$ \\
\hline \multicolumn{8}{|l|}{ Meat-meal-fed: } \\
\hline Dry matter & $32 \cdot 9$ & $23 \cdot 4$ & 0.78 & 0.45 & $0 \cdot 10$ & 0.01 & 0.02 \\
\hline Lysine & 854 & $153 \cdot 0$ & - & $15 \cdot 5$ & - & 0.02 & 0.10 \\
\hline Methionine & 217 & $61 \cdot 6$ & - & $7 \cdot 8$ & - & 0.04 & 0.13 \\
\hline Cystine & 210 & $86 \cdot 7$ & - & $3 \cdot 8$ & - & 0.02 & 0.04 \\
\hline Arginine & 1214 & $156 \cdot 2$ & - & 11.9 & - & 0.01 & 0.08 \\
\hline Threonine & 805 & 130.7 & - & $11 \cdot 7$ & - & 0.01 & 0.09 \\
\hline Isoleucine & 497 & 85.8 & - & $10 \cdot 1$ & - & 0.02 & 0.12 \\
\hline Valine & 850 & $136 \cdot 1$ & - & $12 \cdot 1$ & - & 0.01 & 0.09 \\
\hline
\end{tabular}

* Amount voided in excreta during the $48 \mathrm{~h}$ bioassay or amount present in the caeca at the end of the $48 \mathrm{~h}$ bioassay.

Table 6. Regression coefficients obtained from multiple regression analysis of amino acid composition (mmol/mol total $A A$ ) of excreta $(\mathrm{Y})$ on those of dietary protein $\left(\mathrm{X}_{1}\right)$, endogenous protein $\left(\mathrm{X}_{2}\right)$ and microbial protein $\left(\mathrm{X}_{3}\right)$ in the digestibility assay

(Mean regression coefficients with their standard errors)

\begin{tabular}{|c|c|c|c|c|c|c|c|}
\hline \multirow[b]{3}{*}{ Excreta source $(Y)$} & \multicolumn{6}{|c|}{ Independent variables $(X)$} & \multirow[b]{3}{*}{$r^{2}$} \\
\hline & \multicolumn{2}{|c|}{$\begin{array}{c}\text { Dietary } \\
\text { protein }\left(X_{1}\right)\end{array}$} & \multicolumn{2}{|c|}{$\begin{array}{l}\text { Endogenous } \\
\text { protein }\left(X_{2}\right) \dagger\end{array}$} & \multicolumn{2}{|c|}{$\begin{array}{c}\text { Microbial } \\
\text { protein }\left(X_{3}\right)_{\ddagger}^{\ddagger}\end{array}$} & \\
\hline & Mean & SE & Mean & SE & Mean & SE & \\
\hline Caecectomized, meat-meal-fed & $0.97 * *$ & $0 \cdot 34$ & $0 \cdot 23$ & $0 \cdot 32$ & $0 \cdot 09$ & $0 \cdot 25$ & 0.83 \\
\hline Conventional, meat-meal-fed & $0-91^{* *}$ & $0 \cdot 16$ & 0.06 & $0-15$ & $0 \cdot 21^{*}$ & 0.11 & 0.95 \\
\hline Caecectomized, fasted & ND & ND & $0.93 * *$ & $0 \cdot 16$ & $0 \cdot 06$ & $0 \cdot 14$ & 0.86 \\
\hline Conventional, fasted & ND & ND & $0 \cdot 60^{* *}$ & 0.16 & $0 \cdot 26^{*}$ & $0 \cdot 14$ & 0.85 \\
\hline
\end{tabular}

ND, not determined since birds consumed no dietary protein.

Regression coefficient significantly different from zero: ${ }^{*} P<0 \cdot 10,{ }^{* *} P<0 \cdot 05$.

$\dagger$ Endogenous protein collected at the terminal ileum of surgically modified cockerels given a nitrogen-free diet (Parsons et al. 1983).

$\ddagger$ Microbial cells harvested from poultry excreta (Parsons et al. 1981). 
Table 7. Regression coefficients obtained from multiple regression analyses of amino acid compositions (mmol/mol of total AA) of excreta or caecal contents $(\mathrm{Y})$ on those of dietary protein $\left(\mathrm{X}_{1}\right)$, endogenous protein $\left(\mathrm{X}_{2}\right)$ and microbial protein $\left(\mathrm{X}_{3}\right)$ in the caecal amino acid assay

(Mean regression coefficients with their standard errors)

\begin{tabular}{|c|c|c|c|c|c|c|c|}
\hline \multirow{3}{*}{ 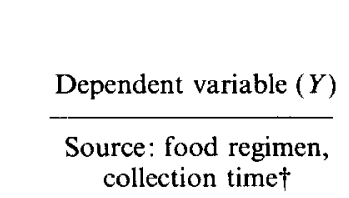 } & \multicolumn{7}{|c|}{ Independent variables $(X)$} \\
\hline & \multicolumn{2}{|c|}{$\begin{array}{c}\text { Dietary } \\
\text { protein }\left(X_{1}\right)\end{array}$} & \multicolumn{2}{|c|}{$\begin{array}{l}\text { Endogenous } \\
\text { protein }\left(X_{2}\right)_{\ddagger}^{\ddagger}\end{array}$} & \multicolumn{2}{|c|}{$\begin{array}{c}\text { Microbial } \\
\text { protein }\left(X_{3}\right) \S\end{array}$} & \multirow[b]{2}{*}{$r^{2}$} \\
\hline & Mean & SE & Mean & SE & Mean & $\mathrm{SE}$ & \\
\hline Excreta: meat meal, $12 \mathrm{~h}$ & $0.96^{*}$ & $0 \cdot 25$ & $0 \cdot 17$ & $0 \cdot 24$ & 0.07 & $0 \cdot 18$ & 0.89 \\
\hline Excreta: meat meal, $48 \mathrm{~h}$ & $0-94^{*}$ & 0.21 & $0 \cdot 21$ & 0.19 & 0.05 & $0 \cdot 15$ & 0.92 \\
\hline Caeca: meat meal, $12 \mathrm{~h}$ & $0.88^{*}$ & $0 \cdot 34$ & 0.09 & $0 \cdot 32$ & $0 \cdot 31$ & 0.26 & 0.84 \\
\hline Caeca: meat meal, $48 \mathrm{~h}$ & 0.26 & $0 \cdot 16$ & 0.12 & $0 \cdot 15$ & $0 \cdot 55^{*}$ & $0 \cdot 11$ & 0.94 \\
\hline Excreta: fasted, $48 \mathrm{~h}$ & ND & ND & $0.71^{*}$ & $0 \cdot 19$ & $0 \cdot 15$ & $0 \cdot 16$ & 0.82 \\
\hline Caeca: fasted, $12 \mathrm{~h}$ & ND & ND & $0 \cdot 13$ & $0 \cdot 10$ & $0.71^{*}$ & 0.08 & 0.93 \\
\hline Caeca: fasted, $48 \mathrm{~h}$ & ND & ND & 0.22 & $0 \cdot 13$ & $0.65^{*}$ & $0 \cdot 11$ & 0.93 \\
\hline
\end{tabular}

ND, not determined since birds consumed no dietary protein.

Regression coefficient significantly different from zero: ${ }^{*} P<0 \cdot 05$.

+ Excreta and caecal contents collected at 12 and $48 \mathrm{~h}$ from fasted cockerels or meat meal-fed cockerels.

$\ddagger$ Endogenous protein collected from the terminal ileum of surgically modified cockerels given a nitrogen-free diet (Parsons et al. 1983).

$\S$ Microbial cells harvested from poultry excreta (Parsons et al. 1981).

$(P<0.05)$ for both CONV and CEC cockerels given meat meal. The coefficient for dietary protein was significantly greater $(P<0.05)$ than those for endogenous and microbial protein with CONV cockerels given meat meal, but not for CEC cockerels given meat meal. The regression coefficient for microbial protein approached significance $(P<0 \cdot 10)$ for CONV cockerels given meat meal, but not for CEC cockerels. For both fasted, CONV and fasted, CEC cockerels, coefficients for endogenous protein were larger than those for microbial protein, with differences between coefficients being significant $(P<0.05)$ for CEC cockerels but not for CONV cockerels $(P>0 \cdot 10)$. The coefficient for microbial protein approached significance $(P<0 \cdot 10)$ for fasted, CONV cockerels but not for fasted, CEC cockerels.

In the caecal AA assay (Table 7), regression coefficients for dietary protein were predominant for excreta voided by meat-meal-fed cockerels at 12 and $48 \mathrm{~h}$ after feeding. Similar results were obtained for caecal contents at $12 \mathrm{~h}$ from cockerels given meat meal. Caecal contents from meat-meal-fed cockerels at $48 \mathrm{~h}$, however, were mainly influenced by microbial protein. With fasted birds, the regression coefficient for endogenous protein was much larger than that for microbial protein when excreta were evaluated, whereas the reverse was true when caecal contents were evaluated.

\section{DISCUSSION}

It is well known that the protein and AA quality of meat meals varies greatly (Johnston \& Coon, 1979a). The meat meal evaluated in the present study was subjected to preliminary determinations of pepsin digestibility and available lysine by chick growth assay before conducting the remaining experiments. These assays indicated that availability of AA in the meat meal was considerably less than $1 \cdot 00$. It was deemed necessary to evaluate a meat 
meal containing only partially available AA to facilitate detection of differences among assay methodologies. Indeed, the availability of AA in the meat meal may have been below normal since its pepsin digestibility was lower than those reported for several meat and bone meals by Johnston \& Coon (1979b).

The results of the present study clearly show that the caeca influence excretion of AA and energy that are of dietary origin. It has also been reported previously that the caeca affect endogenous AA excretion (Kessler et al. 1981; Parsons, 1984). Parsons (1984) hypothesized that microbial proteolysis and deamination of AA in the caeca might largely explain the reduced excretion of AA by fasted, CONV birds compared with fasted, CEC birds. The present study indicates that caecal retention of endogenous AA may also partially account for these differences. The levels of AA present in the caeca of fasted cockerels at the end of a $48 \mathrm{~h}$ assay were substantial when compared with those voided in excreta during the assay.

The influence of caecectomy on AA digestibility and TME values for meat meal was substantial. CONV cockerels consistently yielded higher values than CEC cockerels, with these differences being greater than those observed previously for distillers' dried grains with solubles (Parsons, 1985). Moreover, the caecal AA assay clearly showed that these effects were not due to retention of DM and AA in the caeca. These results strongly suggest that microbial metabolism in the caeca was largely responsible for differences between CONV and CEC birds. Multiple regression analyses of excreta AA profiles indicated microbial influence $(P<0 \cdot 10)$ on AA excretion by CONV cockerels but not for CEC cockerels in the digestibility assay. Similar analyses for the caecal AA assay indicated a substantial flow of non-digested dietary AA into the caeca of cockerels given meat meal. The AA in the caeca $12 \mathrm{~h}$ after feeding appeared to be primarily of dietary origin, whereas those present in the caeca $48 \mathrm{~h}$ after feeding appeared to be mainly of microbial origin (Table 7 ). This suggests that significant amounts of non-digested dietary AA moved into the caeca and were subsequently metabolized by the caecal microflora. Proteolysis or AA deamination or both was probably the primary mode of microbial metabolism since the CONV cockerels excreted a much lower level of AA than did CEC cockerels. Much of the ammonia produced was probably absorbed from the caeca and excreted via the urine (Mortensen, 1984). This would explain the similar N balance observed for CEC and CONV cockerels given meat meal.

The higher TME values obtained with CONV cockerels suggest significant volatile fatty acid production by bacteria in the caeca (Annison et al. 1968). Thus, caecectomy may have reduced the ability of the cockerels to utilize the energy in meat meal. Kessler \& Thomas (1981) reported that TME values for soya-bean meal were lower for CEC than for CONV cockerels. Eggum et al. (1982) and Eggum \& Chwalibog (1983) also reported that addition of Nebacitin (bacitracin + neomycin sulphate) reduced both DM digestibility and metabolizable energy when added to the diets of rats. The present study indicates that the use of CEC birds in digestibility trials could underestimate the amount of energy which may be metabolized by CONV birds.

True digestible AA values for CEC cockerels were in better agreement with availability values using chicks than were true digestible AA values for CONV cockerels. Values for CEC cockerels and chicks were generally in good agreement whereas values for CONV cockerels were higher than those for chicks. Assuming that the chick values were reasonably accurate, digestibility values for CONV cockerels overestimated AA availability. On the other hand, digestibility values of sixteen measured AA for CEC and CONV cockerels were highly correlated $(r 0.83, P<0.01)$. Thus, although values from $C E C$ cockerels were more accurate estimates of AA availability, values from CONV cockerels did reflect large relative differences in AA availability. This observation suggests that digestibility values determined 
with CEC cockerels could be used to develop correction factors for those determined with CONV cockerels, hence, compensating for the overestimation of AA availability by the latter. However, much more research on several samples of meat meals is needed to test this hypothesis.

Chick AA availability values computed from partitioned weight gains were consistently higher than those computed from total weight gains. As discussed by Netke \& Scott (1970), these differences were probably due mainly to variations in voluntary feed consumption among chicks on the test diets. The partitioning of growth to reflect only gain attributable to the specific AA supplement represents an attempt to adjust for differences in feed intake. Chicks given diets supplemented with the crystalline AA standard consumed more feed and, thus, more basal $\mathrm{AA}$, than chicks given diets supplemented with meat meal. Hence, the partitioning procedure yielded higher AA availability values. These results suggest that availability estimates based on partitioned growth are more accurate than those based on total growth particularly if large differences in feed intake exist among treatments.

Cystine had the lowest availability of all measured AA in meat meal. Other researchers have also reported poor availability of cystine in animal protein meals (Baker et al. 1981; Engster et al. 1985). The low digestibility of cystine is due mainly to the effects of processing (Eggum, 1970; Baker et al. 1981). The high requirement for this AA by poultry, relative to other species, and its variable availability in feed ingredients, emphasizes the need for accurate cystine availability values when formulating poultry diets.

The present study shows that the caeca influence AA and energy excretion by poultry and that the use of CONV birds in digestibility trials may result in overestimation of AA availability. Thus, the CEC bird is a better model for assessing AA availability than is the CONV bird. The $48 \mathrm{~h}$ digestibility assay evaluated herein with CEC cockerels has great future potential for rapid and routine determination of AA availability in feedingstuffs for poultry. It is also likely that these availability values may be applicable to other simple-stomach species such as swine and rats.

Appreciation is expressed to Heather Mangian and Daniel Grunloh for conducting the amino acid analyses, and to Martha Cohen-Parsons for developing the computer programs used to summarize the amino acid data.

\section{REFERENCES}

Achinewhu, S. C. \& Hewitt, D. (1979). British Journal of Nutrition 41, 559-571.

Annison, E. F., Hill, K. J. \& Kenworthy, R. (1968). British Journal of Nutrition 22, 207-216.

Association of Official Analytical Chemists (1975). Official Methods of Analysis, 12th ed. Washington, DC: Association of Official Analytical Chemists.

Baker, D. H. (1978). Proceedings of Maryland Nutrition Conference, pp. 1-12.

Baker, D. H., Blittenthal, R. C., Boebel, K. P., Czarnecki, G. L., Southern, L. L. \& Willis, G. M. (1981). Poultry Science 60, 1865-1872.

Baker, D. H., Robbins, K. R. \& Buck, J. S. (1979). Poultry Science 58, 749-750.

Boebel, K. P. \& Baker, D. H. (1982). Poultry Science 61, 1167-1175.

Combs, G. F., Bossard, E. H. \& Childs, G. R. (1968). Feedstuffs 40(8), 36-37.

de Meulenaere, H. J. H., Chen, M.-L. \& Harper, A. E. (1967). Journal of Agricultural and Food Chemistry 15, $310-317$

Eggum, B. O. (1970). Acta Agriculturea Scandinavica 20, 230-234.

Eggum, B. O. \& Chwalibog, A. (1983). Zeitschrift für Tierphysiologie, Tierernährung und Futtermittelkunde 49 , $104-114$.

Eggum, B. O., Thorbek, G., Beames, R. M., Chwalibog, A. \& Henckel, S. (1982). British Journal of Nutrition 48 , 161-175.

Elwell, D. \& Soares, J. H. (1975). Poultry Science 54, 78-85.

Engster, H. M., Cave, N. A., Likuski, H., McNab, J., Parsons, C. M. \& Pfaff, F. E. (1985). Poultry Science 64, 487-498. 
Finney, D. J. (1978). Statistical Method of Biological Assay, 3rd ed. High Wycombe, Bucks; Charles Griffin \& Co. Ltd.

Johnston, J. \& Coon, C. N. (1979a). Poultry Science 58, 919-927.

Johnston, J. \& Coon, C. N. (1979b). Poultry Science 58, 1271-1273.

Katz, R. S. \& Baker, D. H. (1975). Poultry Science 54, 584-591.

Kessler, J. W., Nguyen, T. H. \& Thomas, O. P. (1981). Poultry Science 60, 1576-1577.

Kessler, J. W. \& Thomas, O. P. (1981). Poultry Science 60, 2639-2647.

Mendes-Periera, E., Pion, R. \& Prugnaud, J. (1977). Annals for Biology of Animal Biochemistry and Biophysics 17, 625-631.

Mortensen, A. (1984). In Current Perspectives in Microbial Ecology, pp. 273-278 [M. J. Klus and C. A. Reddy, editors]. Washington, DC: American Society of Microbiology.

National Research Council (1977). Nutrient Requirements of Domestic Animals, vol. 1, Nutrient Requirements of Poultry. Washington, DC: National Academy of Sciences.

Netke, S. P. \& Scott, H. M. (1970). Journal of Nutrition 100, 281-288.

Parsons, C. M. (1984). British Journal of Nutrition 51, 541-548.

Parsons, C. M. (1985). Journal of Agricultural Science, Cambridge 104, 469-472.

Parsons, C. M., Edmonds, M. S. \& Baker, D. H. (1984). Poultry Science 63, 2438-2443.

Parsons, C. M., Potter, L. M. \& Bliss, B. A. (1982). Poultry Science 61, 2241-2246.

Parsons, C. M., Potter, L. M. \& Brown, R. D. Jr (1981). Poultry Science 60, 2687-2696.

Parsons, C. M., Potter, L. M. \& Brown, R. D. Jr (1983). Poultry Science 62, 483-489.

Robbins, K. R. \& Baker, D. H. (1980). Journal of Nutrition 110, 907-915.

Salter, D. N. (1973). Proceedings of the Nutrition Society 32, 65-71.

Salter, D. N. \& Coates, M. E. (1971). British Journal of Nutrition 26, 55-69.

Salter, D. N., Coates, M. E. \& Hewitt, D. (1974). British Journal of Nutrition 31, 307-318.

Salter, D. N. \& Fulford, R. J. (1974). British Journal of Nutrition 32, 625-637.

Sasse, C. E. \& Baker, D. H. (1974). Poultry Science 53, 652-662.

Sibbald, I. R. (1976). Poultry Science 55, 303-308.

Sibbald, I. R. (1979). Poultry Science 58, 668-673.

Sibbald, I. R. (1983). Animal Research Centre, Ottawa. Contribution 83-1, pp. 16-21. Ottawa, Canada: Animal Research Centre.

Soares, J. H. Jr, Miller, D., Fitz, N. \& Sanders, M. (1971). Poultry Science 50, 1134-1143.

Steel, R. G. D. \& Torrie, J. H. (1960). Principles and Procedures of Statistics. New York: McGraw-Hill Book Co., Inc.

Terpstra, K. (1977). Proceedings of Fifth International Symposium on Amino Acids, pp. 1-8. Budapest.

Zebrowska, T. (1973). Roczniki Nauk Rolniczych Series B, 95, 85-89. 